\title{
Binding of Tomato Spotted Wilt Virus to a 94-kDa Thrips Protein
}

\author{
Marjolein Kikkert, Cor Meurs, Fennet van de Wetering, Simone Dorfmüller, \\ Dick Peters, Richard Kormelink, and Rob Goldbach
}

Wageningen Agricultural University, Department of Virology, Binnenhaven 11, 6709 PD Wageningen, the Netherlands. Accepted for publication 8 October 1997.

\begin{abstract}
Kikkert, M., Meurs, C., van de Wetering, F., Dorfmüller, S., Peters, D., Kormelink, R., and Goldbach, R. 1998. Binding of tomato spotted wilt virus to a $94-\mathrm{kDa}$ thrips protein. Phytopathology 88:63-69.

Using protein blot assays, a $94-\mathrm{kDa}$ thrips protein was identified that exhibited specific binding to tomato spotted wilt virus (TSWV) particles. Renaturation of the 94-kDa protein, which is conserved among the two major vector species of TSWV, Frankliniella occidentalis and Thrips tab$a c i$, was crucial for its virus-binding properties, whereas under the same

proteins. The $94-\mathrm{kDa}$ protein species was present in all developmental stages of both vectoring thrips, whereas it was present mainly in the adult stage of a nonvectoring thrips species, Parthenothrips dracenae. Using antibodies against the different TSWV structural proteins, the G2 envelope glycoprotein was identified as the viral determinant involved. Because the virus-binding protein is present throughout the thrips body, but not in the gut, it may represent a receptor protein involved during circulation of the virus through its vector but probably not during viral uptake in the midgut.
\end{abstract} conditions no specific binding was observed with aphid (Myzus persicae)
Tomato spotted wilt virus (TSWV), the type species of the genus Tospovirus within the arthropod-borne family Bunyaviridae, is transmitted by thrips (Thysanoptera) in a propagative manner (23, $29)$. In addition to a polymerase (L protein), nucleoprotein $(\mathrm{N})$, and two nonstructural (NSs and NSm) proteins, the tripartite ambisense RNA genome of TSWV encodes two envelope glycoproteins, G1 and G2, that are expressed from a common precursor gene $(8,9)$. These glycoproteins are thought to be involved mainly in uptake by and replication within the thrips vector but are not essential for systemic infection of plants (17).

The most common vector of TSWV, the Western flower thrips (Frankliniella occidentalis), is increasingly distributed throughout the world, and the spread of the vector is the main cause of a dramatic emergence of TSWV and other tospoviruses in vegetable and ornamental crops worldwide (9).

Because the interaction between viruses and their vectors is crucial in the natural infection cycle, many researchers have focused on epidemiological as well as molecular aspects of this interaction. For an increasing number of plant viruses, more information has become available about the intrinsic factors affecting vector specificity and competence, and for some propagatively transmitted viruses, molecular data have been obtained that describe in detail the different steps of the interaction between virus and vector (1). For different virus-vector combinations, several dissemination barriers must be overcome during circulation of the virus through its vector. Sequentially, these could be the mesenteron or midgut infection (MI), midgut escape (ME), salivary gland infection, and salivary gland escape barriers $(1,10)$. All of these barriers could involve receptor-mediated processes, directing regulated circulation of the virus through the vector coupled to several rounds of replication at specific sites.

Corresponding author: D. Peters; E-mail address: Dick.Peters@medew.viro.wau.nl

Publication no. P-1997-1121-01R

(C) 1998 The American Phytopathological Society
For TSWV, two rounds of viral replication have been identified during circulation. The first round takes place in the cells of the midgut, and the second major round takes place in the salivary glands $(21,22,24,28)$. Ullman et al. (22) suggested a ME barrier in F. occidentalis that may be blocked in the adult stage, thus explaining why adult thrips can transmit TSWV only after they have ingested the virus during their larval stage.

The molecular processes that take place after ingestion of the virus remain to be resolved. However, glycoproteins G1 and G2, which are exposed at the surface of the enveloped particle, are the obvious candidates for being viral attachment proteins, directing viral entry into thrips tissues.

In this paper, specific molecular interactions between TSWV proteins and proteins of the thrips vectors are investigated, using virus overlay assays as previously used to characterize luteovirusaphid interactions (25). Our results suggest specific binding of the viral G2 protein to an approximately $94-\mathrm{kDa}$ protein that is conserved between $F$. occidentalis and Thrips tabaci, two major vectors of TSWV.

\section{MATERIALS AND METHODS}

Isolation of TSWV particles. All binding studies were performed with the Brazilian TSWV isolate BR-01 (5), which was maintained in Nicotiana rustica plants by mechanical inoculation and thrips transmission. Intact, enveloped virus particles were isolated from infected $N$. rustica plants as described by Kikkert et al. (11). Preparations were kept on ice and used immediately or promptly frozen in liquid nitrogen and stored at $-80^{\circ} \mathrm{C}$. Before use, samples were thawed slowly on ice.

Thrips cultures and aphids. Cultures of virus-free $F$. occidentalis were reared on bean pods (Phaseolus vulgaris cv. Prelude) and $T$. tabaci cultures on leek at $27 \pm 0.5^{\circ} \mathrm{C}$ with a 16 -h photoperiod (16 h of light per $8 \mathrm{~h}$ of dark). Colonies were started with adults collected from a greenhouse infestation in the Netherlands. To obtain uniformly aged larvae, fresh bean pods were placed in the thrips colonies for 1 day to achieve egg oviposition. The thrips Parthenothrips dracenae, which has never been re- 


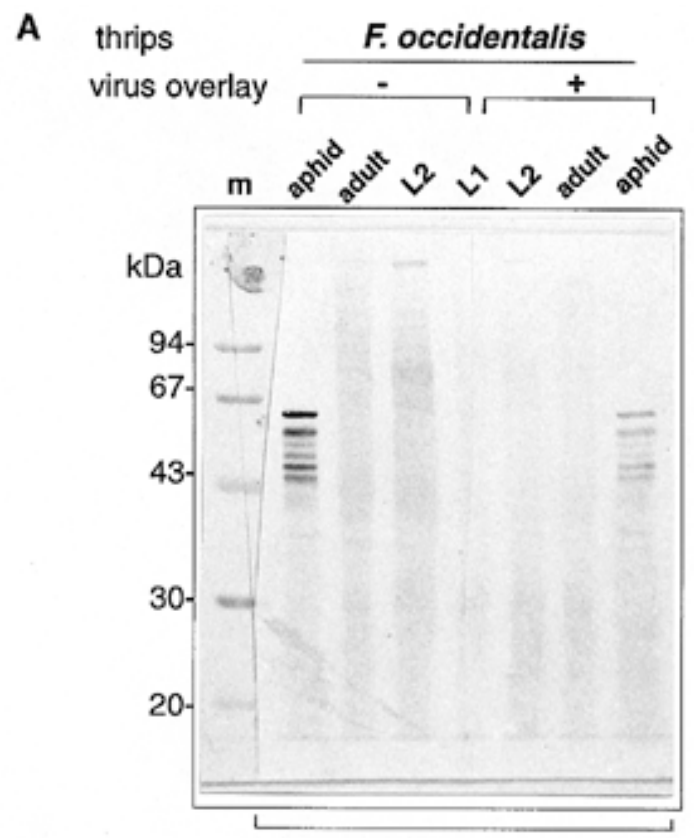

anti G1/G2

B

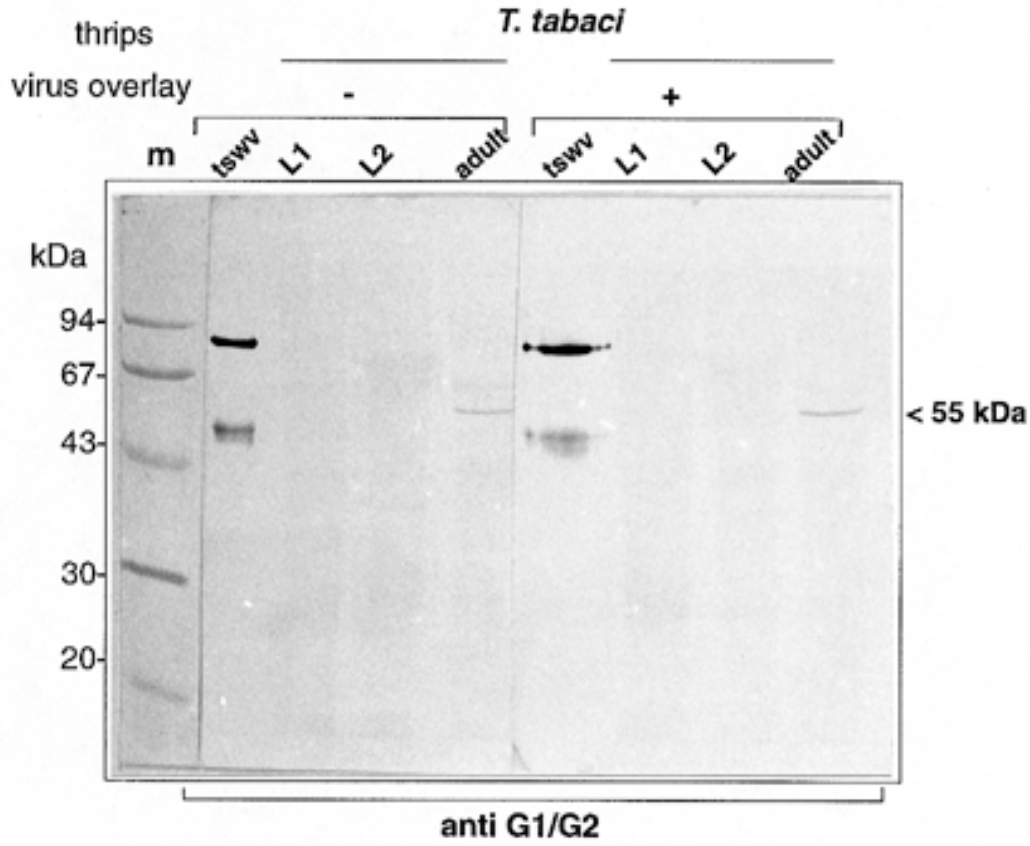

C

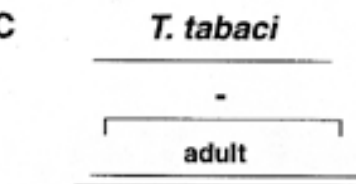

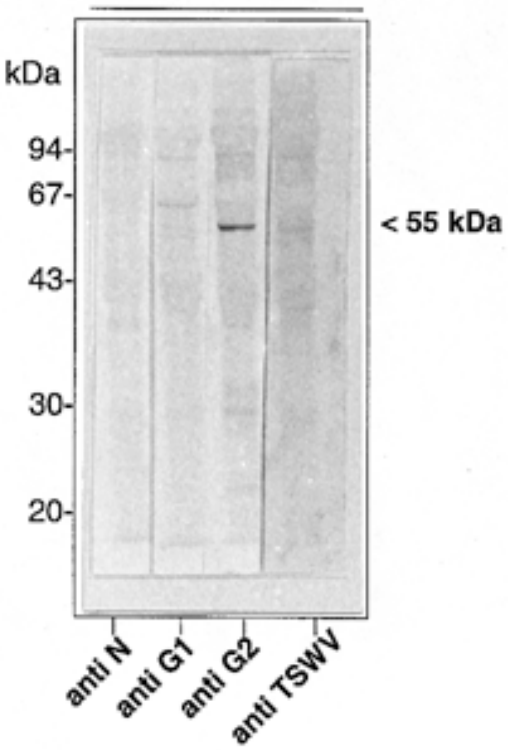

Fig. 1. Tomato spotted wilt virus (TSWV) overlay studies on denatured thrips and aphid proteins ( $30 \mu \mathrm{g}$ of insect protein per lane, blotted onto polyvinylidene fluoride membrane). A, TSWV overlay on proteins of Frankliniella occidentalis L1 and L2 larvae and adults and adult aphids (Myzus persicae), using mixed anti-G1 and -G2 sera after overlay with overlay buffer $(-)$ or overlay buffer containing TSWV particles $(+)$. $\mathrm{m}=$ molecular mass marker. B, TSWV overlay on proteins of Thrips tabaci larvae and adults. TSWV = purified TSWV particles. C, Denatured T. tabaci adult proteins overlaid with overlay buffer without virus and treated with several antisera.

ported as transmitting virus, were reared on Hedera helix plants. Aphids (Myzus persicae) were reared on Brassica napus ssp. oleifera (oilseed rape) plants. Larvae and adults of the different thrips species and aphids were collected, placed in microcentrifuge tubes, frozen in liquid nitrogen, and stored at $-80^{\circ} \mathrm{C}$ prior to further manipulation.

Polyclonal antibodies. Polyclonal antisera against viral glycoproteins G1 and G2, N, and complete TSWV particles were produced as described previously $(5,11)$. Anti-brome mosaic virus (BMVcp) serum was supplied by B. J. M. Verduin (Wageningen Agricultural University, Wageningen, the Netherlands).
Protein electrophoresis and Western blot. Frozen or fresh insects were ground in PBST $\left(0.14 \mathrm{M} \mathrm{NaCl}, 1 \mathrm{mM} \mathrm{KH} \mathrm{PO}_{4}, 8 \mathrm{mM}\right.$ $\mathrm{Na}_{2} \mathrm{HPO}_{4}, 2.5 \mathrm{mM} \mathrm{KCl}$, and $0.05 \%$ Tween 20) to a final concentration of approximately $3 \mu \mathrm{g}$ of protein per ml (estimated by a BioRad [Richmond, CA] protein assay). Protein sample buffer (13) was added, and the samples were boiled for $5 \mathrm{~min}$. A total of $30 \mu \mathrm{g}$ of insect protein per lane was loaded on a sodium dodecyl sulfate (SDS) polyacrylamide gel. After electrophoresis, proteins were blotted onto polyvinylidene fluoride membrane by a BioRad semidry blotting procedure. To verify equal amounts of protein in each lane, gels also were stained with Coomassie brilliant blue. 


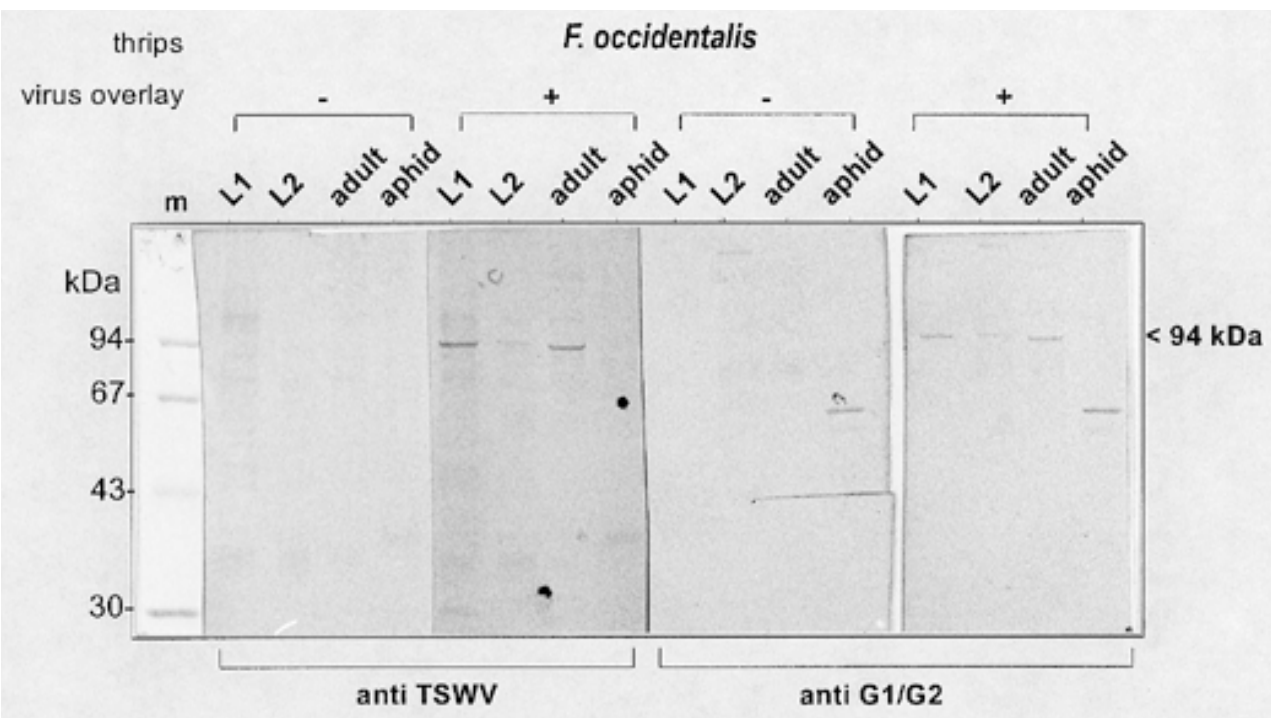

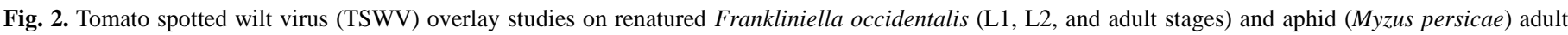

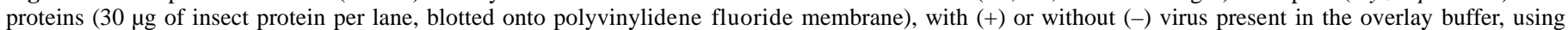
anti-TSWV serum and mixed anti-G1 and -G2 sera. $\mathrm{m}=$ molecular mass marker.

Renaturation of blots. Western blots of insect proteins were renatured essentially as described by de Jong et al. (6), with some modifications. Blots were washed three times for $10 \mathrm{~min}$ each in binding buffer $(25 \mathrm{mM}$ Tris- $\mathrm{HCl}, \mathrm{pH} 7.5,50 \mathrm{mM} \mathrm{NaCl}, 2 \mathrm{mM}$ dithioreitol [DTT], $2 \mathrm{mM}$ EDTA, 0.3\% bovine serum albumin [BSA], and $0.025 \%$ Nonidet P-40 [BDH Laboratory Supplies, Poole, England, UK]) at room temperature (RT). Subsequently, the blots were incubated for $45 \mathrm{~min}$ in denaturing buffer $(7 \mathrm{M}$ guanidine hydrochloride, 50 mM Tris-HCl, pH 8.0, 2 mM DTT, 2 mM EDTA, and $0.3 \% \mathrm{BSA}$ ) at RT. Blots were washed four times for $5 \mathrm{~min}$ each in renaturation buffer $(25 \mathrm{mM}$ Tris- $\mathrm{HCl}, \mathrm{pH} 7.5,50 \mathrm{mM}$ $\mathrm{NaCl}, 2 \mathrm{mM}$ DTT, and $2 \mathrm{mM}$ EDTA) followed by overnight incubation in the same buffer at RT.

Virus overlay assays. The protocol used was basically as described by van den Heuvel et al. (25), with some modifications. Western blots were washed twice for 5 min each in blocking buffer (PBST, 5\% Elk [skim instant milk] [Campina Melkunie, BV. Eindhoven, the Netherlands) and subsequently incubated for $30 \mathrm{~min}$ in overlay buffer (PBST, 5\% Elk, and 2\% polyvinylpyrrolidone). Blots were incubated for 1 to $2 \mathrm{~h}$ in overlay buffer containing $5 \mu \mathrm{g}$ of virus particles per ml. After washing three times for 10 min each in diluted blocking buffer (PBST and 0.5\% Elk), blots were incubated with antiserum against complete TSWV particles or against one or more of the structural proteins (N, G1, and $\mathrm{G} 2$ ) at $1 \mu \mathrm{g} / \mathrm{ml}$ in diluted blocking buffer for $1 \mathrm{~h}$ at RT. After washing with diluted blocking buffer, antigen-antibody complexes were detected with $0.5 \mu \mathrm{g}$ of alkaline phosphatase-conjugated goat anti-rabbit immunoglobulins, $0.33 \mathrm{mg}$ of nitroblue tetrazolium, and $0.165 \mathrm{mg}$ of bromochloroindolyl phosphate per $\mathrm{ml}$ as a substrate.

Protease treatment of virus. TSWV particles were isolated from $100 \mathrm{~g}$ of infected $N$. rustica leaves as described earlier (11), but the sucrose gradient at the end of the procedure was omitted. Virus particles were treated with bromelain (Sigma-Aldrich Chemical Co., St. Louis) based on the protocol described by Mohamed (16). The virus suspension was divided into four portions, which were treated as follows: $20 \mathrm{~min}$ on ice in double-distilled water (portion 1); $20 \mathrm{~min}$ at $37^{\circ} \mathrm{C}$ in protease buffer $\left(1 \mathrm{mM} \mathrm{K}_{2} \mathrm{HPO}_{4}\right.$,

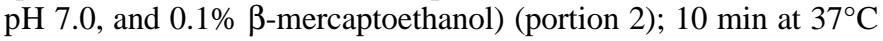
and $10 \mathrm{~min}$ on ice in protease buffer containing $2.5 \mathrm{mg}$ of bromelain per $\mathrm{ml}$ (portion 3); and $20 \mathrm{~min}$ at $37^{\circ} \mathrm{C}$ in protease buffer containing $2.5 \mathrm{mg}$ of bromelain per $\mathrm{ml}$ (portion 4). The four portions were loaded separately on 10 to $40 \%$ sucrose gradients. After centrifugation, the opalescent band was collected from each gradient, diluted with sterile double-distilled water, and pelleted

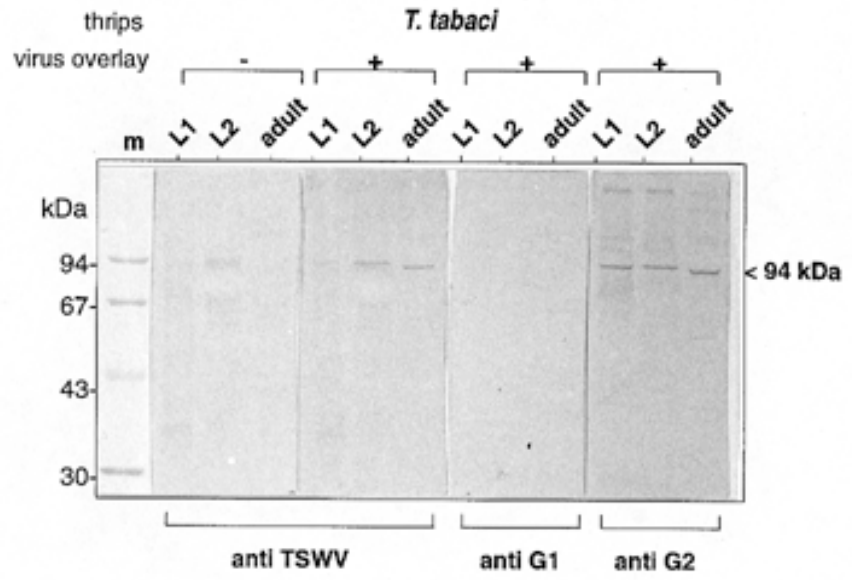

Fig. 3. Tomato spotted wilt virus (TSWV) overlay studies on renatured Thrips tabaci L1, L2, and adult proteins $(30 \mu \mathrm{g}$ per lane, blotted onto polyvinylidene fluoride membrane), with (+) or without (-) virus present in the overlay buffer, using anti-TSWV serum and anti-G1 and -G2 sera. $\mathrm{m}=$ molecular mass marker.

by ultracentrifugation. The resulting virus pellets were resuspended in double-distilled water. The samples were used in overlay assays at $5 \mu \mathrm{g} / \mathrm{ml}$. The integrity of the particles after different treatments was checked by electron microscopy with a simple phosphotungstic acid stain (27).

Dissection of thrips larvae. L2 larvae of $F$. occidentalis were dissected by cutting off the head and transferring the body to a drop of water, resulting in release of the gut from the body. Heads, guts, and remaining body parts were pooled separately. In another experiment, L2 larvae were cut in two behind the thorax. Front and back parts were pooled separately. The samples were prepared for SDS polyacrylamide gel electrophoresis (SDS-PAGE) as described for whole insects, except they were not adjusted for equal protein content but instead for an equal number of animals from which body parts (or whole bodies) originated. A protein sample prepared from body parts of approximately 10 animals was loaded per lane.

\section{RESULTS}

Specific binding of TSWV to a 94-kDa thrips protein. Recently, a virus overlay assay that enabled identification of proteins 
of vectoring aphids that specifically bind to luteoviruses was described (25). In the current study, a similar overlay assay was applied, including a protein renaturation step, to monitor specific binding of TSWV to thrips proteins. When the renaturation step was omitted from the protocol, nonspecific binding to $F$. occidentalis, as well as to aphid proteins, was observed (Fig. 1A). Moreover, in adult $T$. tabaci a clear signal was obtained with a $55-\mathrm{kDa}$ protein species and anti-G1/G2 serum after overlay, but this protein also was detected when TSWV particle overlay was omitted from the assay (Fig. 1B). Further analysis revealed a direct binding of anti-G2 (and anti-TSWV) serum to this 55-kDa thrips protein (Fig. 1C). Addition of Tween 20 to the binding buffer resulted in the loss of the nonspecific binding in other assays.

After renaturation of the proteins on Western blots, a discrete protein band, comigrating with the 94-kDa molecular mass marker protein, was found repeatedly after overlay with TSWV particles in both F. occidentalis and T. tabaci (Figs. 2 and 3, respectively). This protein species was detected in all of the developmental

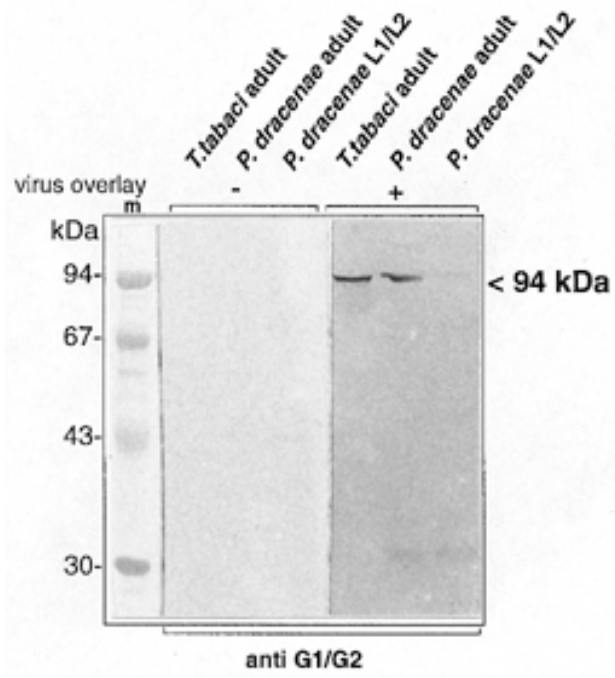

Fig. 4. Tomato spotted wilt virus (TSWV) overlay on renatured Parthenothrips dracenae proteins of adults and pooled L1 and L2 larvae (30 $\mu \mathrm{g}$ per lane, blotted onto polyvinylidene fluoride membrane), with (+) or without (-) virus present in the overlay buffer. $\mathrm{m}=$ molecular mass marker. stages examined for both vectoring thrips species. In control experiments in which virus was omitted from the overlay assay, no reaction with the 94-kDa thrips protein was found (Fig. 2, lanes 2 through 5 and 10 through 13 and Fig. 3, lanes 2 through 4). No specific binding of TSWV particles to aphid proteins was observed (Fig. 2, lanes 5, 9, 13, and 17). The 94-kDa protein also was found in a nonvectoring thrips species, $P$. dracenae, although predominantly in the adult stage and to a much lesser extent in the larval (L1 and L2) stages (Fig. 4).

To study whether the $94-\mathrm{kDa}$ protein is present in complex or multimeric forms, virus overlays were done on nonreduced, renatured proteins of $F$. occidentalis and T. tabaci. No other reacting protein bands were detected in these experiments, suggesting that the $94-\mathrm{kDa}$ protein is present as a monomer (data not shown). Overlay with purified TSWV nucleocapsids devoid of envelopes or with purified BMV particles on renatured proteins of $T$. tabaci larvae or adults did not result in a specific signal (data not shown). To investigate whether the $94-\mathrm{kDa}$ protein may originate from intestinal bacteria in thrips, three strains of the major gut bacteria of $F$. occidentalis, Enterobacter agglomerans, were subjected to SDS-PAGE, blotted and renatured, and overlaid with TSWV particles (data not shown). Because no binding to proteins of any of these bacteria was observed, the $94-\mathrm{kDa}$ protein is probably a genuine thrips protein.

Binding of glycoprotein G2 to the 94-kDa thrips protein. To investigate which of the proteins of the virus particle binds to the 94-kDa thrips protein, several antisera raised against the separate structural TSWV proteins were used after overlay. The $94-\mathrm{kDa}$ protein was detected only with anti-G2 and -TSWV sera (Figs. 2 and 3), not with antibodies against G1 alone (Fig. 3) or N (data not shown). These results suggest that during overlay incubation with virus, only G2 became firmly bound to the $94-\mathrm{kDa}$ thrips protein; the other structural proteins apparently were washed away, probably as a result of the collapse of the enveloped virus particles during the procedure.

Binding of virus through one of the glycoproteins was further confirmed by assays with virus particles pretreated with bromelain, which cleaved both glycoproteins but did not affect the nucleoprotein inside the particle (16). Electron micrograph pictures of bromelain- and buffer-treated TSWV particles showed that bromelain left the spherical integrity of the particles intact but removed the "fuzzy" surface of untreated particles (Fig. 5), as was earlier shown by Mohamed (16) for TSWV and Brand and Shekel (4)
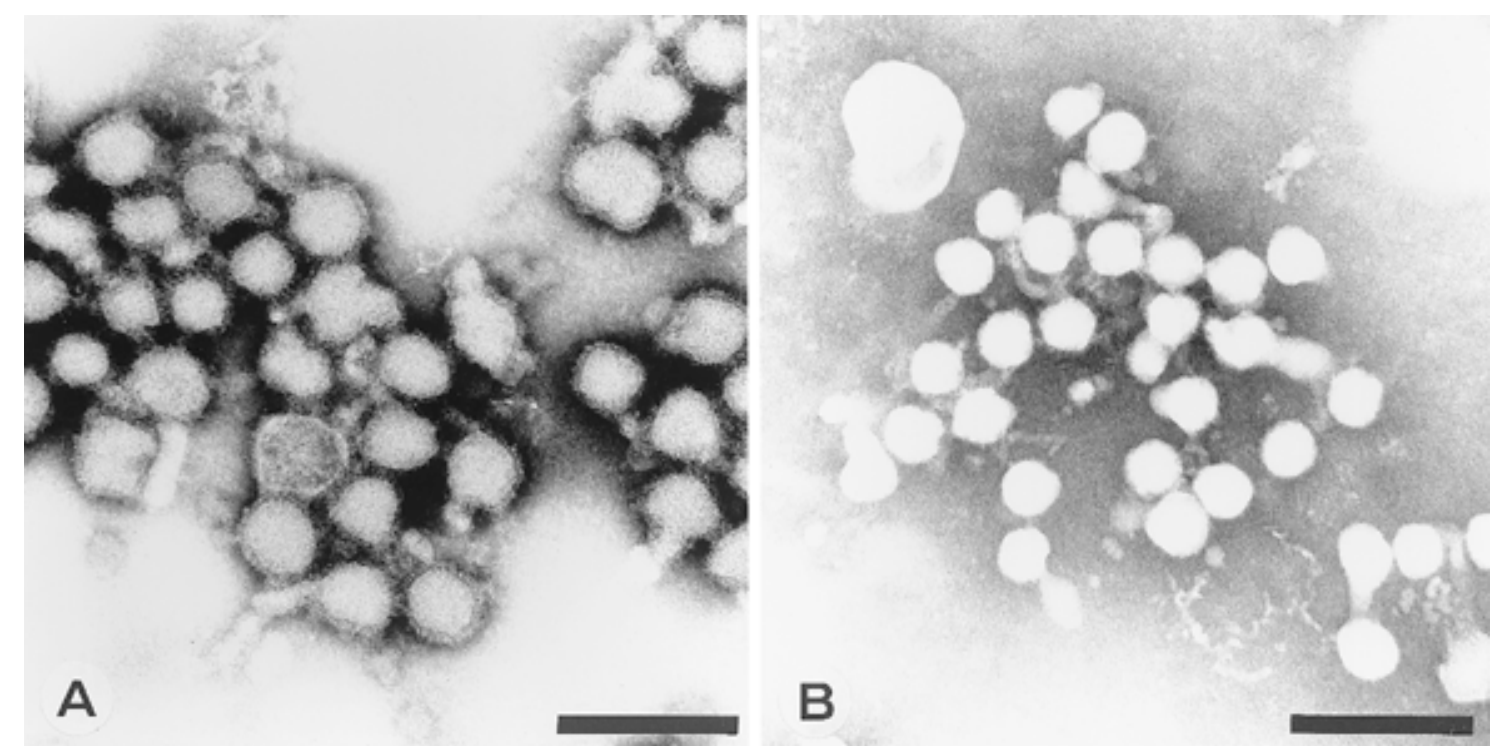

Fig. 5. Electron micrographs of phosphotungstic acid-stained A, buffer-treated tomato spotted wilt virus (TSWV) particles $\left(20\right.$ min at $\left.37^{\circ} \mathrm{C}\right)$ and $\mathbf{B}$, bromelain-treated TSWV particles $\left(10 \mathrm{~min}\right.$ at $\left.37^{\circ} \mathrm{C}\right)$. Bars $=200 \mathrm{~nm}$. 
for influenza virus particles. Using renatured blots with $T$. tabaci adult-stage proteins, we demonstrated that virus samples treated only with buffer $\left(20 \mathrm{~min}\right.$ at $37^{\circ} \mathrm{C}$ ) could still bind to the $94-\mathrm{kDa}$ thrips protein (Fig. 6C, lane 3), albeit somewhat less profoundly than in the untreated control (Fig. 6C, lane 2). However, samples treated with bromelain for $10 \mathrm{~min}$ at $37^{\circ} \mathrm{C}$ lost their binding capacity completely (Fig. 6C, lane 4). Based on Western blot analysis of bromelain-treated samples (Fig. 6B, lanes 3 and 7), we concluded that these virus particles contained some intact G1 but lacked G2, suggesting that the $94-\mathrm{kDa}$ protein normally is recognized by $\mathrm{G} 2$ rather than G1. Twenty minutes of bromelain treatment cleaved both G1 and G2 almost completely (Fig. 6B, lanes 4 and 8) and resulted, as expected, in virus particles unable to bind to thrips protein (Fig. 6C, lane 5). Taken together, these studies confirm that the $94-\mathrm{kDa}$ thrips protein is recognized by the G2 glycoprotein of TSWV.

Lack of relationship of the 94-kDa thrips protein with the midgut. The 94-kDa protein of $F$. occidentalis and T. tabaci that binds to the TSWV G2 protein may be a receptor protein that plays a key role in the interaction between TSWV and its vectors at one of the dissemination barriers during circulation. To obtain a first indication of where the $94-\mathrm{kDa}$ protein is localized within the thrips body, L2 larvae of $F$. occidentalis were separated into three (head, gut, and remaining body parts) or two (front and back, cut behind thorax) parts. Overlay assays of proteins from these separated body parts showed that the $94-\mathrm{kDa}$ thrips protein was found in the head, the remaining body part that lacked the gut, and in the front and back parts of L2 larvae but was clearly absent in the gut system of the insect (Fig. 7). Because the back part of the larvae contained the $94-\mathrm{kDa}$ protein, we can safely conclude that the binding is not exclusively associated with the salivary glands. Instead, our results indicate that the $94-\mathrm{kDa}$ protein is present throughout the body of the L2 larvae and could be associated with a specific organ or tissue, such as the hemolymph or fat body.

\section{DISCUSSION}

The use of overlay studies to investigate binding of virus to proteins of the vector is a feasible, straight-forward method that has yielded important results in luteovirus research (25). Using this method, however, we could not detect specific bind-

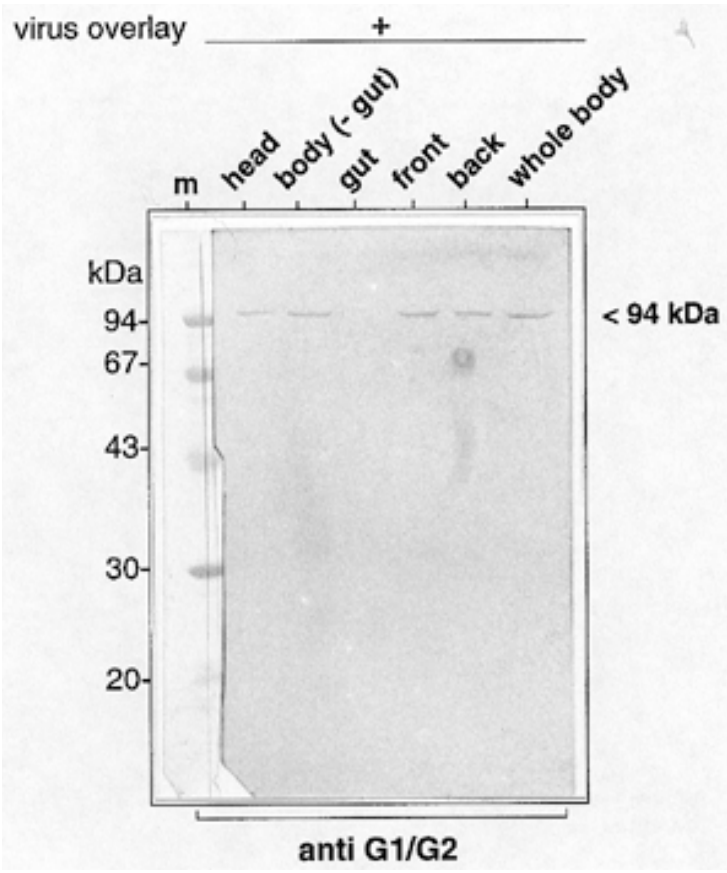

Fig. 7. Tomato spotted wilt virus (TSWV) overlay on proteins of body parts of Frankliniella occidentalis. Each lane contained 10 body parts or whole bodies, proteins were blotted onto polyvinylidene fluoride membrane. $\mathrm{m}=$ molecular mass marker.

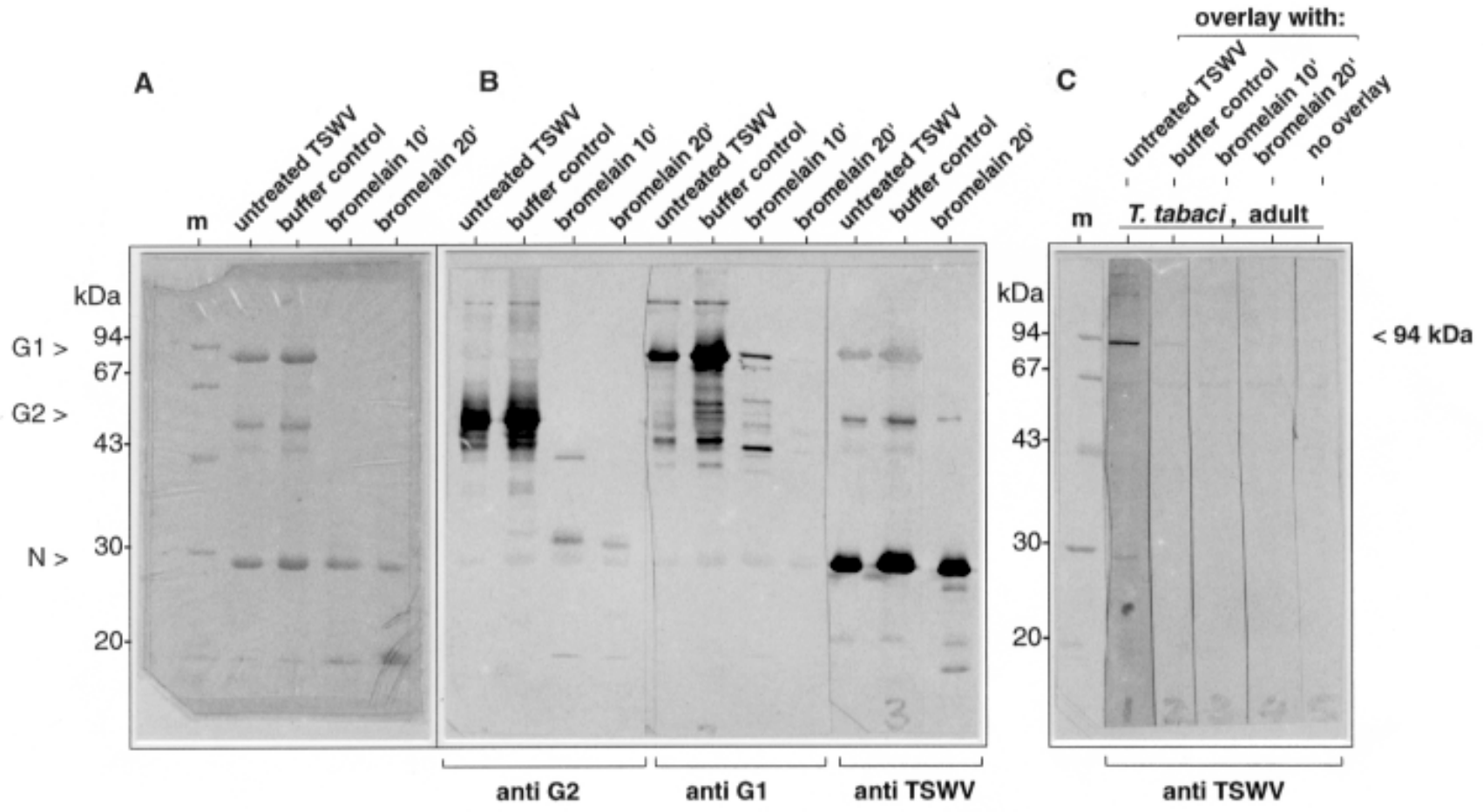

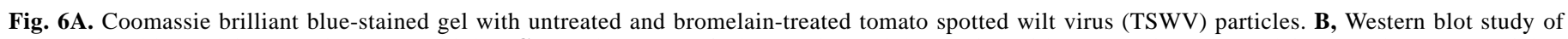

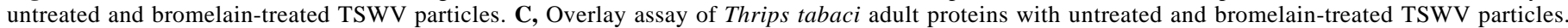

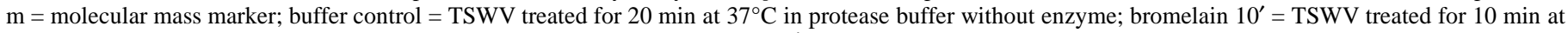

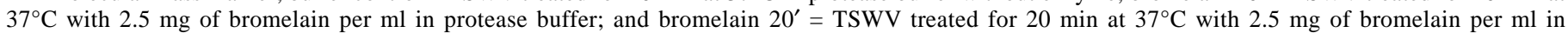
protease buffer. 
ing of TSWV to any protein of either F. occidentalis or T. tabaci.

We observed a clear binding of TSWV particles to a single, conserved thrips protein of approximately $94 \mathrm{kDa}$ only after renaturation of proteins on Western blots, by which presumably the secondary structure of the thrips proteins was somewhat restored. The protein was present in all stages examined of the two vectoring thrips species, $F$. occidentalis and $T$. tabaci. The slightly faster migration of the binding band in $F$. occidentalis and $T$. tabaci (Figs. 2 and 3) adults, probably is due to interference by an abundant protein that is only present in adults and that migrates slightly slower than the 94-kDa protein, as observed in Coomassie brilliant blue-stained gels (data not shown).

The virus-binding 94-kDa protein also was found in the nonvectoring thrips species $P$. dracenae (Fig. 4), albeit not in its larval stages. Transmission studies demonstrated that virus acquisition must take place during the larval stage in order for the thrips to become viruliferous in older larval and adult stages $(20,26,29)$, suggesting that at least the majority of the replication and circulation events of the virus take place before the adult stage is reached. A possible role of the identified $94-\mathrm{kDa}$ thrips protein could be somewhere along this circulation process during the larval stages, thus possibly explaining the inability of $P$. dracenae to transmit TSWV.

Further experiments showed that TSWV-G2 is the viral protein that binds to the $94-\mathrm{kDa}$ thrips protein. The presence of an RGD motif near the $\mathrm{N}$ terminus of $\mathrm{G} 2$ (12) might be an important determinant in attachment to thrips tissue, because, for example, foot and mouth disease virus (7) and coxsackievirus $(3,18,19)$ RGD motifs are important for cell attachment. Further experiments must reveal whether the RGD motif is involved in the binding of G2 to the $94-\mathrm{kDa}$ thrips protein.

Dissection of F. occidentalis L2 larvae seemed to show that the 94-kDa protein is not present in the gut. In this experiment, we used body parts of 10 animals per lane, which resulted in an unequal amount of protein per lane but would give a binding signal similar to whole bodies if the $94-\mathrm{kDa}$ protein was concentrated in one of the parts. The head and gut fractions particularly contained relatively low amounts of protein due to the lower volume of these body parts (data not shown), which could have masked a signal in the gut fraction in overlay experiments. However, because we did find a clear $94-\mathrm{kDa}$ protein signal in the head fraction, we argue that if there was a reasonable amount of 94-kDa protein in the gut fraction, we would have found a signal there as well. The results of this experiment indicate that the $94 \mathrm{kDa}-$ G2 interaction is unlikely to be involved in a MI or ME barrier but rather in other stages of circulation.

This conclusion is supported indirectly by experiments with protease digestion of virus particles that use bromelain (Fig. 6) and trypsin (data not shown), which show that G2 seems more sensitive to proteases than G1. It is tempting to assume that the viral protein that is the most protease sensitive does not play a major role in receptor binding in the midgut, because the gut lumen of the insect usually contains very high concentrations of proteases $(14,15)$. In this view, and consistent with our results, G2 would not be an obvious candidate for establishing binding to midgut cells.

Bandla et al. (2) recently identified a $50-\mathrm{kDa} F$. occidentalis protein that is able to bind to the TSWV glycoproteins and apparently is present in the midgut of the insect, using similar overlay assays. It is remarkable that we do not find binding of TSWV proteins to gut-related thrips proteins, whereas such an interaction is certainly expected to enable entry of virus into gut cells. One explanation is based on the methodology used in our binding studies, which may have excluded certain interactions that are actually present in vivo that are dependent on environmental aspects such as $\mathrm{pH}$ and salt concentration. Small differences in experimental circumstances, thus, may account for the identification of a different thrips pro- tein by Bandla et al. (2). Binding assays that use other circumstances and experimental set-ups may elucidate additional important interactions between TSWV and thrips proteins.

\section{ACKNOWLEDGMENTS}

We thank J. J. Fransen of the Research Station for Floriculture and Glasshouse Vegetables, Aalsmeer, the Netherlands, for providing Parthenothrips dracenae thrips; E. de Vries, University of Amsterdam, Amsterdam, the Netherlands, for providing different strains of Enterobacter agglomerans; and B. J. M. Verduin, Department of Virology, Wageningen Agricultural University, Wageningen, the Netherlands, for purified brome mosaic virus and anti-BMV serum preparations.

\section{LITERATURE CITED}

1. Ammar, E. D. 1994. Propagative transmission of plant and animal viruses by insects: Factors affecting vector specificity and competence. Adv. Dis. Vector Res. 10:289-331.

2. Bandla, M., Westcot, D., Sherwood, J., and Ullman, D. E. 1996. Thrips midgut proteins that bind to tomato spotted wilt tospovirus glycoproteins: Proceedings of the international symposium on tospoviruses and thrips of floral and vegetable crops. Acta Hortic. 431:341-349.

3. Berinstein, A., Roivainen, M., Hovi, T., Mason, P., and Baxt, B. 1995. Antibodies to the vitronectin receptor (integrin $\alpha_{v} \beta_{3}$ ) inhibit binding and infection of foot-and-mouth disease virus to cultured cells. J. Virol. 69:2664-2666.

4. Brand, C. M., and Shekel, J. J. 1972. Crystalline antigen from the influenza virus envelope. Nature (Lond.) 238:145-147.

5. de Ávila, A., de Haan, P., Smeets, M., Resende R. de O., Kormelink, R., Kitajima, E., Goldbach, R., and Peters, D. 1993. Distinct levels of relationships between tospovirus isolates. Arch. Virol. 128:211-227.

6. de Jong, R., de Laaf, L., Vennema, H., and Meijlink, F. 1992. DNA-binding activity of the murine homeodomain protein produced by a hybrid phage T7/vaccinia virus system. Gene 116:195-203.

7. Fox, G., Parry, N., Barnett, P., McGinn, B., Rowlands, D., and Brown, F 1989. The cell attachment site on foot-and-mouth disease virus includes the amino acid sequence RGD (arginine-glycine-aspartic acid). J. Gen. Virol. 70:625-637.

8. German, T. L., Ullman, D. E., and Moyer, J. W. 1992. Tospoviruses: Diagnosis, molecular biology, phylogeny and vector relationships. Annu. Rev. Phytopathol. 30:315-348.

9. Goldbach, R. W., and Peters, D. 1996. Molecular and biological aspects of tospoviruses. Pages 129-157 in: The Bunyaviridae. R. M. Elliott, ed. Plenum Press, New York.

10. Hardy, J., Houk, E., Kramer, L., and Reeves, W. 1983. Intrinsic factors affecting vector competence of mosquitoes for arboviruses. Annu. Rev. Entomol. 28:229-262.

11. Kikkert, M., van Poelwijk, F., Storms, M., Kassies, W., Bloksma, H., van Lent, J., Kormelink, R., and Goldbach, R. 1997. A protoplast system for studying tomato spotted wilt virus infection. J. Gen. Virol. 78:1755-1763.

12. Kormelink, R., de Haan, P., Meurs, C., Peters, D., and Goldbach, R. 1992. The nucleotide sequence of the M-RNA segment of tomato spotted wilt virus, a bunyavirus with two ambisense RNA segments. J. Gen. Virol. 73:2795-2804

13. Leammli, U. K. 1970. Cleavage of structural proteins during the assembly of the head of bacteriophage T4. Nature (Lond.) 227:680-685.

14. Ludwig, G., Christensen, B., Yuill, Th., and Schultz, K. 1989. Enzyme processing of LaCrosse virus glycoprotein G1: A bunyavirus-vector infection model. Virology 171:108-113.

15. Ludwig, G., Israel, B., Christensen, B., Yiull, Th., and Schultz, K. 1991. Role of LaCrosse virus glycoproteins in attachment of virus to host cells. Virology 181:564-571.

16. Mohamed, N. A. 1981. Isolation and characterization of subviral structures from tomato spotted wilt virus. J. Gen. Virol. 53:197-206.

17. Resende, R. de O., de Haan, P., de Ávila, A. C., Kitajima, E. W., Kormelink, R., Goldbach, R. W., and Peters, D. 1991. Generation of envelope and defective interfering RNA mutants of tomato spotted wilt virus by mechanical passage. J. Gen. Virol. 72:2375-2383.

18. Roivainen, M., Hyypiä, T., Piirainen, L., Kalkkinen, N., Stanway, G., and Hovi, T. 1991. RGD-dependent entry of coxsackievirus A9 into host cells and its bypass after cleavage of VP1 protein by intestinal proteases. J. Virol. 65:4735-4740.

19. Roivainen, M., Piirainen, L., Hovi, T., Virtanen, I., Riikonen, T., Heino, J., and Hyypiä, T. 1994. Entry of coxsackievirus A9 into host cells: Specific interactions with $\alpha_{v} \beta_{3}$ integrin, the vitronectin receptor. Virology 203:357365 .

20. Sakimura, K. 1962. The present status of thrips-borne viruses. Pages 30- 
40 in: Biological Transmission of Disease Agents. K. Maramorosh, ed. Academic Press, New York.

21. Tsuda, S., Fujisawa, I., Ohnishi, J., Hosokawa, D., and Tomaru, K. 1996. Localization of tomato spotted wilt tospovirus in larvae and pupae of the insect vector Thrips setosus. Phytopathology 86:1199-1203.

22. Ullman, D. E., Cho, J. J., Mau, R. F. L., Westcot, D. M., and Custer, D. M. 1992. A midgut barrier to tomato spotted wilt virus acquisition by adult Western flower thrips. Phytopathology 82:1333-1342.

23. Ullman, D. E., German, T. L., Sherwood, J. L., Westcot, D. M., and Cantone, F. A. 1993. Tospovirus replication in insect vector cells: Immunocytochemical evidence that the nonstructural protein encoded by the S RNA of tomato spotted wilt tospovirus is present in thrips vector cells. Phytopathology 83:456-463.

24. Ullman, D. E., Westcot, D. M., Chenault, K. D., Sherwood, J. L., German, T. L., Bandla, M. D., Cantone, F. A., and Duer, H. L. 1995. Compartmentalization, intracellular transport, and autophagy of tomato spotted wilt tospovirus proteins in infected thrips cells. Phytopathology 85:644-654.

25. van den Heuvel, J., Verbeek, M., and van der Wilk, F. 1994. Endosymbiotic bacteria associated with circulative transmission of potato leafroll virus by Myzus persicae. J. Gen. Virol. 75:2559-2565.

26. van de Wetering, F., Goldbach, R., and Peters, D. 1996. Tomato spotted wilt tospovirus ingestion by first instar larvae of Frankliniella occidentalis is a prerequisite for transmission. Phytopathology 86:900-905.

27. van Lent, J., Storms, M., van der Meer, F., Wellink, J., and Goldbach, R. 1991. Tubular structures involved in movement of cowpea mosaic virus are also formed in infected cowpea protoplasts. J. Gen. Virol. 72:2615-2623.

28. Wijkamp, I., and Peters, D. 1993. Determination of the median latent period of two tospoviruses in Frankliniella occidentalis, using a novel leaf disk assay. Phytopathology 83:986-991.

29. Wijkamp, I., van Lent, J., Kormelink, R., Goldbach, R., and Peters, D. 1993. Multiplication of tomato spotted wilt virus in its insect vector, Frankliniella occidentalis. J. Virol. 74:341-349. 